\title{
Perlindungan Hukum Ahli Waris Dan Kreditur Persekutuan Komanditer Ketika Meninggalnya Sekutu Komplementer
}

\author{
Riky Rustam dan Rizky Miraningsih \\ Fakultas Hukum Universitas Islam Indonesia \\ Jln. Tamansiswa No. 158 Yogyakarta \\ rikyrustam@uii.ac.id; Dhonyko_01@yahoo.com
}

Received: 4 Februari 2019; Accepted: 20 September 2019; Published: 17 Februari 2020

DOI: 10.20885/iustum.vol26.iss3.art9

\begin{abstract}
This research is motivated by the conceptual conflict between civil inheritance law and company law in the form of commercial partnership (CV). The problems to be examined are first, the concept of legal protection of the rights of the heir to the complementary partner on the inheritance which has become a collateral for the debt of the $\mathrm{CV}$, and second, the formulation of the concept of legal protection given to creditors of the $\mathrm{CV}$ for the death of the complementary partner whose heir is not willing to take responsibility for replacing their predecessor. The method used in this research is normative legal study by collecting library data. The results of this study concluded that first, the new complementary partner must be responsible for the debt of $\mathrm{CV}$. Therefore, the new complementary partner must return the inheritance guarantee to the heir. Second, concurrent creditors must have a copy of the deed of CV to examine who is responsible if undesirable things happen in the CV, as a form of legal protection for themselves.
\end{abstract}

Keywords: Commanditaire Vennotschap (CV); inheritance; CV creditors; heirs

Abstrak

Penelitian ini dilatarbelakangi adanya pertentangan konseptual antara hukum waris perdata dan hukum badan usaha yang berbentuk persekutuan komaditer (CV). Permasalahan yang dikaji adalah mengenai pertama, konsep perlindungan hukum terhadap hak ahli waris sekutu komplementer atas harta warisan yang telah menjadi jaminan utang CV., Kedua, rumusan konsep perlindungan hukum yang diberikan kepada kreditur CV atas meninggalnya sekutu komplementer dan ahli waris sekutu tersebut tidak bersedia bertanggung jawab menggantikan pewarisnya. Metode yang dipakai dalam penelitian ini adalah penelitian hukum normatif dengan mengumpulan data secara studi pustaka (library research). Hasil penelitian ini menyimpulkan bahwa, pertama, sekutu komplementer yang baru harus bertanggung jawab terhadap utang-utang yang dimiliki CV. Oleh karena itu sekutu komplementer yang baru harus mengembalikan jaminan yang merupakan harta warisan kepada ahli waris. Kedua, kreditur konkuren harus memiliki salinan akta pendirian CV untuk mengetahui siapa yang bertanggung jawab jika terjadi hal-hal yang tidak diinginkan dalam CV, sebagai bentuk perlindungan hukum baginya.

Kata-kata Kunci : Commanditaire vennotschap (CV); harta warisan; ahli waris; kreditur CV 


\section{Pendahuluan}

Kendala yang sering terjadi dalam menjalankan Commanditaire Vennotschap (CV) adalah mengenai kurangnya modal atau pendanaan yang dibutuhkan untuk melakukan kegiatan usaha CV. Kurangnya pendanaan ini dapat terjadi karena CV ingin memperbesar usahanya atau karena modal yang dimiliki CV memang sudah tidak mencukupi akibat CV mengalami kerugian. Pada umumnya masalah ini akan diselesaikan oleh sekutu komplementer dengan dua cara, yaitu dengan meminta seluruh sekutu untuk menambahkan modal yang mereka setor atau jika cara pertama ini tidak dapat dilakukan maka cara terakhir yang dapat dilakukan adalah dengan meminjam modal dari pihak ketiga berdasarkan perjanjian utang piutang yang pada umumnya disertai dengan pemberian jaminan. ${ }^{1}$

Perjanjian utang piutang yang dilakukan oleh sekutu komplementer untuk dan atas nama CV akan menimbulkan dua akibat hukum, yaitu bagi CV itu sendiri dan bagi sekutu komplementer. Akibat hukum yang pertama adalah munculnya kewajiban bagi CV untuk melakukan pembayaran atas perjanjian utang piutang tersebut. Kedua adalah tanggung jawab atas perjanjian utang piutang itu merupakan tanggung jawab sekutu komplementer secara pribadi untuk keseluruhan jika CV tidak mampu memenuhi kewajibannya membayar utang. ${ }^{2}$

Berdasarkan kedua akibat hukum tersebut, risiko yang menjadi masalah ketika CV memiliki utang adalah jika sekutu komplementer sebagai pihak yang bertanggung jawab atas utang tersebut meninggal dunia. Meninggalnya sekutu komplementer akan sangat berpengaruh terhadap perjanjian utang piutang yang telah dibuat oleh CV. Hal ini dikarenakan, meninggalnya sekutu komplementer akan mengakibatkan CV menjadi bubar (jika tidak diperjanjikan terlebih dahulu dalam akta pendirian $\mathrm{CV}$ bahwa $\mathrm{CV}$ akan tetap berlangsung meskipun salah seorang sekutu CV meninggal dunia), sebagaimana ketentuan Pasal 1646 Sub 4 KUHPerd yang menentukan bahwa salah satu penyebab berakhirnya persekutuan adalah “jika salah seorang sekutu meninggal dunia atau ditaruh di bawah

${ }^{1}$ Kadek Rima Anggen Suari dan I Nengah Suantra, "Tanggung Jawab Sekutu Terhadap Commanditaire Vennootschap (CV) yang Mengalami Pailit”, Kertha Semaya, Fakultas Hukum Universitas Udayana, Vol. 06, No. 02, Maret 2018, hlm. 2.

${ }^{2}$ M. Yahya Harahap, Hukum Perseroan Terbatas, Cetakan Kedua, Sinar Grafika, Jakarta, 2009, hlm. 18-19. 
pengampuan, atau dinyatakan pailit". Meskipun demikian, ketentuan bubarnya $\mathrm{CV}$ tersebut bukanlah ketentuan yang bersifat harga mati. ${ }^{3}$

Bubarnya CV sebagai akibat terpenuhinya ketentuan Pasal 1646 Sub 4 KUHPerd akan mengakibatkan CV bertanggung jawab untuk membayar utangnya meskipun hanya terbatas kepada jumlah modal dan kekayaan yang dimiliki oleh CV. Kelebihan utang CV yang belum terbayarkan akan menjadi tanggung jawab sekutu komplementer secara tanggung renteng untuk keseluruhan, sebagaimana ketentuan Pasal 18 Kitab Undang-Undang Hukum Dagang (KUHD) yang menentukan bahwa "Dalam perseroan firma tiap-tiap persero bertanggung jawab secara tanggung renteng untuk seluruhnya atas perikatan-perikatan perseroannya." Dengan demikian, jika modal dan kekayaan CV tidak cukup untuk melunasi utang, maka kreditur dapat menuntut pelunasan utang tersebut kepada harta pribadi sekutu komplementer yang dalam hal ini harta tersebut menjadi harta peninggalan atau harta waris bagi para ahli waris sekutu komplementer.

Mengesampingkan ketentuan Pasal 1646 Sub 4 KUHPerd di atas, jika dalam akta pendirian CV telah diperjanjikan bahwa CV akan tetap berlangsung meskipun salah seorang sekutu meninggal dunia, maka pengurusan CV akan dilanjutkan oleh sekutu-sekutu komanditer lainnya yang masih hidup. Sesuai dengan ketentuan Pasal 1651 KUHPerd, pengurusan CV tersebut juga harus diteruskan oleh ahli waris dari sekutu yang meninggal dunia sepanjang diperjanjikan dalam CV. ${ }^{4}$ Ahli waris sekutu yang meninggal tersebut memiliki hak atas pembagian keuntungan sebesar hak yang dimiliki sekutu yang meninggal dunia dan ahli waris tersebut juga menanggung kerugian yang timbul dari perbuatan sekutu komplementer sebelum meninggal dunia.

Pembuatan akta pendirian CV yang di dalamnya memperjanjikan ahli waris untuk meneruskan pengurusan persekutuan setelah meninggalnya salah seorang sekutu tersebut, jika dikaji secara mendalam sebenarnya bertentangan dengan asas perjanjian yaitu asas personalitas sebagaimana yang ditentukan Pasal 1315 KUHPerd. Hal ini dikarenakan ketentuan yang diperjanjikan dalam akta pendirian

3Richard Burton Simatupang, Aspek Hukum Dalam Bisnis (Edisi Revisi), Rineka Cipta, Jakarta, 2004, hlm. 13.

${ }^{4}$ C.S.T Kansil dan Christine S.T. Kansil, Pokok Pokok Pengetahuan Hukum Dagang Indonesia, Cetakan Kedua, Sinar Grafika, Jakarta, 2004, hlm. 78. 
tersebut tidak hanya memberikan hak, tetapi juga memberikan kewajiban kepada ahli waris yang merupakan pihak ketiga dalam akta pendirian (perjanjian) tersebut.

Terjadinya benturan norma di atas menimbulkan masalah tersendiri bagi ahli waris sekutu komplementer dan juga bagi kreditur CV. Masalah tersebut yaitu: pertama, jika ahli waris menolak ketetapan untuk melanjutkan $\mathrm{CV}$, maka akan berakibat ahli waris kehilangan haknya untuk mendapatkan harta waris dikarenakan sesuai ketentuan hukum perdata yang berlaku di Indonesia, jika ahli waris menerima harta waris yang diwariskan kepadanya maka seluruh aktiva (harta) dan juga pasiva (utang) yang dimiliki oleh pewaris akan beralih kepada ahli waris. Dengan demikian, jika ahli waris menolak melanjutkan CV, maka sama halnya dengan ahli waris menolak utang pewaris sehingga ahli waris akan kehilangan haknya atas harta warisan. Begitu juga sebaliknya, jika ahli waris bersedia melanjutkan CV maka ahli waris harus bertanggung jawab atas utang CV yang jumlahnya dapat melebihi harta waris.

Jumlah utang CV yang melebihi harta waris akan mengakibatkan ahli waris kehilangan haknya atas harta waris meskipun ahli waris menyetujui untuk melanjutkan CV. Hal ini akan semakin diperberat jika utang CV tersebut ternyata dibebani suatu jaminan hak tanggungan atas tanah milik sekutu komplementer yang merupakan harta waris bagi ahli waris. Tanggung jawab yang dibebankan kepada ahli waris atas utang yang tidak mereka buat dan merupakan kepentingan pihak lain yaitu CV merupakan bentuk ketidakadilan dan penyalahgunaan keadaan yang akan merugikan ahli waris, bahkan dapat berubah menjadi perbuatan melawan hukum jika sekutu CV yang masih hidup melanggar hak-hak pribadi ahli waris.

Kedua, dengan diwariskannya tanggung jawab atas utang yang dimiliki CV sebagai akibat meninggalnya sekutu komplementer, kreditur yang beritikad baik akan sangat dirugikan karena jika modal dan harta yang dimiliki CV tidak cukup untuk melunasi utang maka kreditur harus meminta pelunasannya kepada ahli waris sekutu komplementer. Jika ahli waris tidak bersedia membayar utang tersebut dengan tidak menerima harta waris yang diwariskan kepadanya, maka akan menyebabkan kreditur kesulitan untuk meminta pelunasan utang CV. 


\section{Rumusan Masalah}

Berdasarkan latar belakang tersebut, Peneliti ingin menggali lebih dalam mengenai, pertama, bagaimanakah perlindungan hukum terhadap hak ahli waris sekutu komplementer atas harta warisan yang telah menjadi jaminan utang CV? Kedua, bagaimanakah perlindungan hukum yang diberikan kepada kreditur CV jika sekutu komplementer meninggal dunia dan ahli waris sekutu tersebut tidak bersedia bertanggung jawab menggantikan pewarisnya?

\section{Tujuan Penelitian}

Tujuan penelitian ini, pertama, untuk merumuskan konsep perlindungan hukum terhadap hak ahli waris sekutu komplementer atas harta warisan yang telah menjadi jaminan utang CV. Kedua, untuk merumuskan konsep perlindungan hukum yang diberikan kepada kreditur CV jika sekutu komplementer meninggal dunia dan ahli waris sekutu tersebut tidak bersedia bertanggung jawab menggantikan pewarisnya.

\section{Metode Penelitian}

Penelitian ini adalah penelitian hukum normatif atau penelitian hukum kepustakaan yang mengumpulkan data secara studi kepustakaan (library research), karena itu data yang digunakan adalah data sekunder yang terdiri dari bahan hukum primer dan bahan hukum sekunder. Semua bahan hukum yang telah dikumpulkan tersebut akan dianalisis secara deskriptif kualitatif dengan menekankan pada penalaran, yang akan membandingkan antara konsep hukum waris perdata dan pertanggungjawan sekutu CV sehingga akan ditemukan order of logic dari permasalahan tersebut sebagai kesimpulan dalam penelitian ini.

\section{Hasil Penelitian dan Pembahasan}

\section{Perlindungan Hukum Terhadap Hak Ahli Waris Sekutu Komplementer atas Harta Warisan yang Telah Menjadi Jaminan Utang CV}

Hukum perusahaan dapat diartikan secara sederhana sebagai hukum yang mengatur perusahaan. Perusahaan atau "badan usaha" adalah organisasi yang bertujuan mencari keuntungan baik yang berbadan hukum maupun non badan hukum. Perusahaan berbadan hukum meliputi Perseroan Terbatas (PT), koperasi 
dan perusahaan mutual (usaha bersama). Sedangkan perusahaan non badan hukum dapat berbentuk perseorangan (Usaha Dagang (UD)) dan persekutuan (Firma, CV, Maatschap). ${ }^{5}$

CV adalah persekutuan yang didirikan atas dasar pejanjian. Menurut sifatnya, perjanjian itu ada dua macam golongan, yaitu perjanjian konsensual dan perjanjian riil. Perjanjian mendirikan CV adalah perjanjian konsensual, yaitu perjanjian yang terjadi karena ada persetujuan kehendak dari pihak atau ada kesepakatan sebelum ada tindakan-tindakan (penyerahan barang). Pada CV, jika sudah ada kata sepakat dari para sekutu untuk mendirikannya, meskipun belum ada inbreng, maka CV sudah dianggap ada. ${ }^{6}$

$\mathrm{CV}$ adalah persekutuan firma yang mempunyai satu atau beberapa orang sekutu komanditer yang menyerahkan sejumlah uang, barang atau tenaga sebagai pemasukan pada persekutuan dan sekutu komanditer tersebut tidak turut campur dalam pengurusan atau penguasaan dalam persekutuan. ${ }^{7}$ Sekutu komanditer memiliki tanggung jawab yang terbatas yaitu hanya terbatas pada jumlah pemasukan yang telah disetorkannya saja dan tidak dapat dituntut sampai kepada harta pribadi sekutu komanditer. ${ }^{8}$ Sedangkan sekutu komplementer bertanggung jawab secara pribadi untuk keseluruhan' ${ }^{9}$ bahkan hingga ke ranah perbuatan pidana sekalipun. ${ }^{10}$ Oleh karena itu, tanggung jawab sekutu dalam CV terbagi menjadi dua bentuk, yaitu: 11

1. Tanggung jawab sekutu komanditer, yang hanya terbatas pada jumlah pemasukan yang telah disetorkannya dan tidak dapat dituntut sampai kepada harta pribadi sekutu komanditer selama sekutu komanditer itu tidak ikut campur dalam pengurusan persekutuan. Jika hal ini dilanggar maka

5 Iswi Hariyani, "Kajian Hukum Restrukturisasi Asuransi Jiwa Bersama Bumiputera 1912 sebagai Perusahaan Mutual”, Jurnal Hukum IUS QUIA IUSTUM, No. 2 Vol. 24 April 2017, hlm. 324.

${ }^{6}$ Julius Caesar Transon Simorangkir, "Tanggung Jawab Sekutu Maatschap Terhadap Pihak Ke 3 dalam Suatu Perjanjian Konsorsium Terkait Bubarnya Maatschap atas Kehendak Para Sekutu (Kasus Perjanjian Konsorsium antara PT Agro Bintang Dharma Nusantara dengan Pemerintah Daerah Balikpapan, Bontang, Kutim dan Paser)", Fiat Justisia Jurnal Ilmu Hukum, Volume 9, No. 2, April-Juni 2015, hlm. 240.

7 HMN Purwosutjipto, Pengertian Pokok Hukum Dagang Indonesia 2 Bentuk-Bentuk Perusahaan, cetakan kesebelas, Djambatan, Jakarta, 2007, hlm. 74.

8 Gunawan Widjaja, Seri Aspek. Hukum dalam Bisnis: Persekutuan Perdata, Persekutuan Firma dan Persekutuan Komanditer, Edisi 1, Cetakan Kedua, Kencana, Jakarta, 2006, hlm. 246-248.

${ }^{9}$ HMN Purwosutjipto, Op. Cit., hlm. 76.

10 Abdul Aziz Alsa, Ningrum Natasya Sirait, et.al., "Pertanggungjawaban Pidana Badan Usaha Berbentuk CV (Commanditaire Vennootschap) Dalam Perlindungan dan Pengelolaan Lingkungan Hidup”, USU Law Journal, Vol. 3. No. 3, November 2015, hlm. 142.

${ }^{11}$ Ibid. 
tanggung jawab sekutu komanditer sama dengan tanggung jawab sekutu komplementer yaitu bertanggung jawab secara pribadi untuk keseluruhan.

2. Tanggung jawab sekutu komplementer atau sekutu aktif yaitu sekutu yang memasukkan modal ke dalam persekutuan dan bertugas mengurus persekutuan. Sekutu komplementer ini bertanggung jawab secara pribadi untuk keseluruhan. Dengan demikian tanggung jawabnya dapat dituntut hingga kepada harta pribadi.

Jika mengkaji konsep pertanggungjawaban sekutu tersebut, teori pertanggungjawaban itu sendiri memiliki konsep yang khusus. Berdasarkan Kamus Besar Bahasa Indonesia (KBBI), pertanggungjawaban dapat dimaknai sebagai suatu yang dipertanggungjawabkan atau perbuatan atau hal yang dipertanggungjawabkan. Dalam kamus hukum terdapat dua istilah mengenai pertanggungjawaban yaitu liability dan responsibility. Istilah liability menunjuk pada pertanggungjawaban hukum, yaitu tanggung gugat akibat kesalahan yang dilakukan oleh subjek hukum. ${ }^{12}$ Sedangkan responsibility menunjuk kepada pertanggungjawaban politik (berkaitan dengan wewenang atau kewajiban seseorang atas suatu tanggung jawab). ${ }^{13}$ Responsibility adalah keharusan seseorang untuk melaksanakan secara selayaknya apa yang telah diwajibkan kepadanya. ${ }^{14}$

Pertanggungjawaban biasanya diartikan sebagai proses antar pribadi yang menyangkut tindakan, perbuatan, atau keputusan seseorang dalam hubungannya dengan orang lain sehingga dapat menerima hak dan wewenang tertentu berikut sanksi yang menjadi konsekuensinya. Pertanggungjawaban mengandung tiga macam konotasi yakni sebagai berikut: 15

1. Pertanggungjawaban sebagai akuntabilitas (accountability).

Konsep ini terbagi menjadi dua yakni akuntabilitas eksplisit (answerability) dan akuntabilitas implisit. Akuntabilitas eksplisit merupakan pertanggungjawaban ketika seseorang diharuskan untuk menjawab atau memikul konsekuensi atas cara-caranya dalam melaksanakan tugas-tugas yang diberikan kepadanya. Sedangkan akuntabilitas implisit yakni seseorang secara implisit bertanggung jawab atas setiap pengaruh yang tidak terduga dari akibat-akibat keputusan yang dibuatnya.

\footnotetext{
12 Ridwan, Hukum Administrasi Negara, Edisi Revisi, Rajawali Press, Jakarta, 2014, hlm. 321.

${ }^{13}$ Ibid.

${ }^{14}$ Ibid.

${ }^{15}$ Herbert J. Spiro dalam Wahyudi Kumortomo, Etika Administrasi Negara, Rajawali Press, Jakarta, 2011,
} hlm. 175-176. 
2. Pertanggungjawaban sebab-akibat (cause).

Pertanggungjawaban ini disebut sebagai pertanggungjawaban secara kausal. Pertanggungjawaban kausal yang eksplisit terdiri dari empat unsur, yaitu sumber (resource), pengetahuan, pilihan, dan maksud (purpose). Keempat unsur secara eksplisit ini harus ada dalam sebuah pertanggungjawaban. Jika salah satu hilang maka pertanggungjawabannya akan menjadi cacat. Sementara pertanggungjawaban kausal secara implisit merupakan landasan pokok bagi pelaksanaan suatu urusan, misalnya kebijakan (virtue), atau kesejahteraan (welfare) buat sesama.

3. Pertanggungjawaban sebagai kewajiban (obligation).

Pertanggungjawaban sebagai kewajiban untuk melakukan sesuatu mempunyai arti bahwa:

a. Kapasitas untuk pertanggungjawaban kausal kepada orang yang memberi delegasi, dalam rangka menyempurnakan hal-hal yang dipertanggungjawabkan.

b. Harus melaksanakan setiap tahapan dari kontribusi kausalnya secara eksplisit.

Berdasarkan teori pertanggungjawaban tersebut, tanggung jawab sekutu komplementer suatu $\mathrm{CV}$ adalah tanggung jawab dalam konsep responsibility sekaligus liability. Bertanggung jawab dalam konsep responsibility karena sekutu komplementer bertanggung jawab untuk melaksanakan wewenang atau kewajibannya mengurus dan mengelola CV. Sedangkan bertanggung jawab dalam konsep liability adalah sebagai wujud kewajiban sekutu komplementer untuk menanggung semua risiko dan kerugian yang terjadi bahkan hingga terjadinya gugatan oleh pihak ketiga di pengadilan.

Tanggung jawab yang dimiliki oleh sekutu komplementer, jika dikaitkan dengan konsep tanggung jawab sebagai akuntabilitas (occountability), sebab-akibat (cause), dan kewajiban (obligation) di atas, akan terus mengikat sekutu komplementer dalam kondisi apapun. Sekutu komplementer akan tetap menanggung risiko dan sanksi-sanksi atas segala tindakan, perbuatan, atau keputusannya kepada orang lain yang terjadi selama menjalankan CV.

Berdasarkan hal tersebut, sekutu komplementer CV tidak hanya bertanggung jawab ketika sekutu tersebut masih berstatus sebagai sekutu CV. Tanggung jawab tersebut tetap melekat kepada sekutu meskipun telah terjadi penggantian kedudukan, mengundurkan diri atau karena meninggalnya sekutu. Kecuali jika hal tersebut telah diperjanjikan secara tegas dalam akta pendirian $\mathrm{CV}$, disetujui secara bulat oleh semua 
sekutu, didaftarkan ke Kepaniteraan Pengadilan Negeri setempat untuk melindungi kepentingan pihak ketiga yang berkepentingan dengan sekutu tersebut. ${ }^{16}$

$\mathrm{CV}$ didirikan berdasarkan perjanjian yang dibuat oleh seluruh sekutu CV. Perjanjian ini yang kemudian akan menjadi akta pendirian $\mathrm{CV}$, karena itu para pihak (komparisi) dalam akta pendirian CV adalah para sekutu yang mendirikan CV. Kedudukan ahli waris dalam akta pendirian CV yang akan tetap berjalan meskipun seorang sekutunya meninggal dunia adalah sebagai pihak ketiga yang menerima manfaat sekaligus kewajiban dari akta pendirian CV tersebut.

Sesuai dengan asas personalitas yang berlaku dalam hukum perjanjian Indonesia, pihak ketiga hanya dapat dibebani kewajiban jika pihak ketiga tersebut menyatakan kesediaannya menerima kewajiban itu. Hal ini berarti bahwa ahli waris sekutu komplementer akan dihadapkan kepada dua bentuk pilihan yang harus dipilih, yaitu:

1. Pilihan bentuk pertama adalah untuk menerima atau menolak harta warisan pewaris.

Hukum perdata Indonesia mengatur bahwa seorang ahli waris dapat menerima atau menolak suatu warisan sebagaimana ketentuan Pasal 1045 KUHPerd. Pasal 1023 ayat (1) dan Pasal 1024 KUHPerd memberikan waktu kepada ahli waris untuk menentukan apakah akan menerima atau menolak harta warisan tersebut selama 4 bulan.

Jika ahli waris menolak harta warisan, sesuai dengan ketentuan Pasal 1058 dan Pasal 1059 KUHPerd, maka:

a. Ahli waris tersebut dianggap tidak pernah menjadi ahli waris.

b. Bagian ahli waris yang menolak tersebut jatuh kepada ahli waris lainnya, ahli waris yang menolak tersebut seakan-akan tidak pernah ada.

Sejak ahli waris memutuskan untuk menolak harta warisan, maka sejak saat itu juga tanggung jawab ahli waris atas CV akan hilang seiring dengan hilangnya hak ahli waris atas harta warisan. Hal ini merupakan konsekuensi hukum atas

${ }^{16}$ HMN Purwosutjipto, Op. Cit., hlm. 58-60. 
keputusan ahli waris untuk menolak harta warisan sebagaimana ditentukan Pasal 1058 dan Pasal 1059 KUHPerd di atas.

2. Pilihan bentuk kedua muncul jika ahli waris pada pilihan pertama di atas memilih untuk menerima harta warisan. Memilih untuk menerima harta warisan akan mengakibatkan ahli waris juga harus menerima kedudukannya sebagai sekutu baru dalam CV menggantikan sekutu komplementer (kecuali jika ahli waris kemudian mengundurkan diri, maka konsekuensinya seperti halnya seorang sekutu yang mengundurkan diri). Dalam hal inilah pilihan bentuk kedua tersebut muncul, yaitu untuk memilih apakah akan menjadi sekutu komplementer dalam CV yang ditinggalkan pewaris atau justru memilih untuk menjadi sekutu komanditer saja. Hal inilah yang menjadi kewajiban bagi ahli waris karena ahli waris memiliki kewajiban untuk mengelola CV menggantikan sekutu komplementer atau kewajiban untuk tetap memberikan hak warisnya sebagai modal pengelolaan CV dalam kedudukan ahli waris tersebut sebagai sekutu komanditer.

Kedua bentuk pilihan tersebut akan memperjelas kedudukan ahli waris dalam pengurusan CV. Kedudukan tersebut akan memberikan kepastian hukum kepada ahli waris mengenai batasan hak dan kewajiban yang dimiliki oleh ahli waris. Dengan demikian, kedudukan harta warisan yang berada dalam CV juga akan semakin jelas status kepemilikannya setelah meninggalnya sekutu komplementer.

Ahli waris ketika menentukan untuk menerima harta waris, maka ahli waris akan memiliki tanggung jawab dan kewajiban terhadap CV sebagai sekutu baru dalam CV, baik sebagai sekutu komplementer maupun sebagai sekutu komanditer. ${ }^{17}$ Jika ahli waris memilih menjadi ahli waris komplementer melanjutkan pewaris, maka ahli waris akan memiliki kewajiban yang sama dengan pewaris untuk menjalankan CV dan bertanggung jawab terhadap utang-utang yang telah ada. Sedangkan, jika ahli waris memilih sebagai sekutu komanditer, maka ahli waris ini hanya berkewajiban untuk memasukan harta ke dalam CV untuk memperkuat modal $\mathrm{CV}^{18}$ dan tidak bertanggung jawab terhadap utang-utang CV yang telah ada, kecuali terhadap utangutang CV yang telah diperjanjikan sebagai kewajiban pewaris dan/atau dapat 
dibuktikan bahwa utang tersebut dimanfaatkan oleh pewaris bukan untuk kepentingan CV melainkan untuk kepentingan pribadinya.

Ahli waris yang memilih sebagai sekutu komanditer, maka akan ada sekutu lain (selain ahli waris) yang akan menggantikan kedudukan sekutu komplementer sebagai sekutu komplementer yang baru. Perubahan kedudukan sekutu yang menggantikan kedudukan sekutu lain ini menimbulkan kewajiban untuk menanggung tanggung jawab sekutu yang digantikan tersebut. Sekutu komanditer yang berubah menjadi sekutu komplementer menggantikan sekutu komplementer yang telah meninggal dunia bertanggung jawab dalam mengelola dan menjalankan CV termasuk di dalamnya untuk menguasai harta kekayaan CV dan juga bertanggung jawab terhadap utang-utang yang dimiliki CV.

Sekutu komplementer baru memiliki kewajiban untuk mengembalikan harta waris sekutu komplementer lama yang telah menjadi jaminan utang CV kepada ahli warisnya, kecuali jika dapat dibuktikan bahwa sekutu komplementer lama memiliki utang kepada CV yang harus dibayarkan dengan jaminan harta waris tersebut. Berbeda halnya jika ahli waris memilih untuk menjadi sekutu komplementer menggantikan pewaris, dalam keadaan ini maka ahli waris sebagai sekutu komplementer baru yang menggantikan kedudukan sekutu yang lama akan bertanggung jawab terhadap utang-utang yang telah ada pada saat masuk menjadi sekutu CV. ${ }^{19}$ Selain keadaan tersebut, ahli waris sekutu komplementer akan tetap bertanggung jawab atas utang CV jika kedudukan pewaris tidak hanya sebagai sekutu komplementer, melainkan sekaligus menjadi penjamin atas utang CV. Dalam keadaan ini tanggung jawab pewaris sebagai penjamin pelunasan utang akan beralih kepada ahli waris. ${ }^{20}$

Pilihan-pilihan keadaan tersebut hanya akan memiliki konsekuensi hukum jika secara tegas ditentukan dalam anggaran dasar pendirian CV. Oleh karena itu, perlindungan hukum yang paling kuat yang dapat diberikan kepada ahli waris adalah klausul-klausul yang ditentukan dalam anggaran dasar CV.

${ }^{19}$ Ibid., hlm. 59.

${ }^{20}$ Lenny Nadriana dan Eman Suparman, "Tanggung Jawab Ahli Waris dari Penjamin pada Perusahaan yang Pailit Ditinjau dari Hukum Waris Islam”, Jurnal Hukum IUS QULA IUSTUM, No. 3 Vol. 24, 28 Februari 2018, hlm. 394. 
Anggaran dasar CV sebagai aturan utama yang harus ditaati dalam suatu CV untuk melindungi kepentingan masing-masing sekutu dan kepentingan pihak ketiga termasuk kepentingan ahli waris sekutu, haruslah ditentukan secara lengkap dan detail. Misalnya ketentuan bahwa CV tidak akan berakhir ketika seorang sekutu meninggal dunia, hak dan kewajiban para sekutu, pembagian keuntungan dan kerugian, pengembalian jaminan yang telah diberikan, batas tanggung jawab sekutu komplementer dan ketentuan tentang perubahan kedudukan sekutu ketika seorang sekutu meninggal dunia harus ditentukan dan disepakati oleh seluruh sekutu ketika CV tersebut akan didirikan. Kesepakatan tersebut harus tercantum secara tegas dalam akta pendirian CV. Tanpa adanya ketentuan itu dalam anggaran dasar CV maka sesuai Pasal 1646 Sub 4 KUHPerd, CV akan berakhir demi hukum.

Satu contoh yang terjadi dalam praktik adalah sebagaimana yang terjadi dalam CV RAI yang berkedudukan di Sleman. ${ }^{21} \mathrm{CV}$ ini didirikan dengan akta notaris nomor 12 tertanggal 25 Maret 2002 di hadapan seorang Notaris di Sleman. CV RAI ini telah berkembang menjadi sebuah $\mathrm{CV}$ besar yang memiliki cabang usaha di beberapa daerah, salah satunya adalah cabang usaha yang terletak di Sumatera.

Cabang usaha CV RAI yang terletak di daerah Sumatera tersebut dikelola oleh salah seorang sekutu komplementer CV RAI yang semula berdomisili di Yogyakarta kemudian pindah ke Sumatera. Seiring berjalannya usaha CV, pada tanggal 11 Maret 2015 sekutu komplementer tersebut meninggal dunia, meninggalkan usaha $\mathrm{CV}$ beserta dengan sejumlah utang kepada relasi bisnis CV.

Pasal 9 Anggaran Dasar CV RAI menentukan bahwa:

Apabila salah seorang persero meninggal dunia, persero tidak harus dibubarkan, tetapi persero-persero yang masih ada bersama-sama dengan ahli waris dari persero yang meninggal dunia itu, berhak untuk melanjutkan (usaha-usaha) perseroan, dengan ketentuan bahwa jika ahli waris terdiri lebih dari seorang, maka para ahli waris (yang memiliki hak bersama-sama) itu harus menunjuk seorang kuasa untuk mewakili dan menjalankan hak-hak dan kewajiban-kewajiban mereka sebagai persero dalam perseroan dalam jangka waktu paling lama 3 (tiga) bulan terhitung dari meninggalnya persero yang bersangkutan. Jika dalam jangka waktu 3 (tiga) bulan itu mereka belum atau

${ }^{21}$ Para sekutu menghendaki untuk status CV dirahasiakan, oleh karena itu dalam penelitian ini identitas CV beserta para sekutunya akan dihilangkan. Penelitian akan fokus kepada akta pendirian dan penyelesaian permasalahan yang sesuai dengan rumusan masalah dalam penelitian ini. 
tidak menunjuk seorang kuasa atau tidak ada pernyataan bahwa mereka setuju untuk melanjutkan (usaha-usaha) perseroan ini, maka mereka dianggap tidak setuju dan dinyatakan telah keluar dari perseroan terhitung sejak hari meninggalnya persero yang bersangkutan dan dalam hal demikian persero yang masih ada berhak untuk melanjutkan (usaha-usaha) perseroan. Dan bagian keuntungan dan kerugian yang diterima oleh persero yang meninggal segera diselesaikan kepada ahli waris.

Ketentuan Pasal 9 Anggaran Dasar CV RAI di atas menunjukan betapa sederhananya klausul yang ditentukan terhadap CV yang tidak bubar dengan meninggalnya salah satu sekutu CV. Selain klausul tersebut, tidak ditemukan lagi klausul yang mengatur mengenai pergantian kedudukan dalam CV. Klausul yang tidak lengkap dan detail seperti inilah yang rentan menimbulkan sengketa di antara para sekutu. Sebagaimana yang terjadi pada CV RAI tersebut, setelah meninggalnya sekutu komplementer CV RAI, terjadi kekosongan hukum mengenai siapakah yang akan bertanggung jawab atas utang CV yang dibuat oleh sekutu komplementer yang meninggal dunia.

Satu-satunya cara menyelesaikan masalah ini adalah dengan kesepakatan para sekutu, sehingga disepakati bahwa sekutu komplementer lainnya yang akan bertanggung jawab atas utang-utang tersebut. Sedangkan terhadap ahli waris diberikan sedikit tunjangan sebagai bentuk sisa keuntungan pewaris setelah dikurangi kerugian dan biaya-biaya lainnya. Di sinilah bukti betapa pentinganya pembuatan anggaran dasar CV yang lengkap dan detail untuk menjamin kepastian hukum kepada seluruh pihak yang terkait dengan CV.

Pasal 9 Anggaran Dasar CV RAI tersebut menunjukan bahwa meskipun kedudukan sekutu komplementer digantikan oleh sekutu lainnya dan tanggung jawab atas utang CV beralih kepada sekutu komplementer baru, ahli waris tetap tidak kehilangan tanggung jawabnya untuk menanggung kerugian yang timbul atas tindakan pewaris. Dengan demikian, ahli waris tetap harus mengeluarkan sebagian harta warisan untuk membayar kerugian yang ada. 
Perlindungan Hukum yang Diberikan Kepada Kreditur CV Jika Sekutu Komplementer Meninggal Dunia dan Ahli Waris Sekutu Tersebut Tidak Bersedia Bertanggung Jawab Menggantikan Pewarisnya

Hukum perdata Indonesia mengenal adanya 2 jenis kreditur, yaitu: 22 pertama, kreditur biasa (konkuren). Pasal 1132 KUHPerd mengatur mengenai kreditur konkuren, yaitu kreditur yang secara bersama-sama memperoleh pelunasan (tanpa ada yang didahulukan) yang dihitung berdasarkan besarnya piutang masing-masing dibandingkan terhadap piutang mereka secara keseluruhan, terhadap seluruh harta kekayaan debitur. Dengan demikian, kreditur konkuren mempunyai kedudukan yang sama atas pelunasan utang dari harta debitur tanpa ada yang didahulukan.

Kedua, kreditur istimewa atau yang sering disebut sebagai kreditur preferen adalah kreditur yang oleh undang-undang, yang karena sifat piutangnya mendapatkan pelunasan terlebih dahulu dan/atau sebagai kreditur pemegang jaminan kebendaan yaitu Hak Tanggungan, Jaminan Hipotek, Gadai, Jaminan Fidusia dan jaminan kebendaan lainnya. Kreditur ini juga memiliki hak istimewa yaitu suatu hak yang oleh undang-undang diberikan kepada seorang berpiutang sehingga tingkatnya lebih tinggi daripada orang yang berpiutang lainnya. ${ }^{23}$

Kedua jenis kreditur di atas memiliki bentuk perlindungan hukum yang berbeda-beda dalam menyelesaikan piutang mereka kepada debitur. Kreditur dengan jaminan hak kebendaan merupakan jenis kreditur yang memiliki perlindungan hukum paling kuat dibandingkan dengan jenis kreditur konkuren. Jaminan kebendaan tersebut memberikan jaminan yang kuat kepada kreditur preferen berdasarkan benda yang dijaminkan sebagai pelunasan atas piutang mereka. ${ }^{24}$

Jaminan kebendaan memberi wewenang kepada kreditur untuk menjual objek yang secara khusus ditunjuk sebagai jaminan dan mengambil pelunasan piutangnya dari hasil penjualan tersebut jika debitur cidera janji atau wanprestasi. Wewenang tersebut juga disertai dengan hak untuk didahulukan pelunasannya daripada kreditur-kreditur yang lain (droit de preference). Jaminan kebendaan juga

22 Jono, Hukum Kepailitan, Cetakan Kedua, Sinar Grafika, Jakarta, 2010, hlm. 5-7.

${ }^{23}$ Baca Pasal 1139 dan Pasal 1149 KUHPerd.

${ }^{24}$ Soebekti, Jaminan-Jaminan untuk Pemberian Kredit Menurut Hukum Indonesia, Alumni, Bandung, 1982, hlm. 25. 
akan tetap membebani objek yang dijadikan jaminan tersebut meskipun dalam tangan siapapun objek tersebut berada (droit de suite). ${ }^{25}$

Masalah yang sesungguhnya adalah mengenai perlindungan hukum yang diberikan kepada kreditur konkuren. Kreditur biasa atau kreditur konkuren adalah kreditur yang paling lemah kedudukannya dibandingkan dengan kreditur istimewa atau preferen, hal ini disebabkan kreditur konkuren tidak memiliki jaminan apapun dari harta milik debitur sebagai pelunasan utang debitur.

Tanpa adanya jaminan khusus yang dikuasai oleh kreditur konkuren, pelunasan utangnya hanya dapat dilakukan dengan mengharapkan iktikad baik dari debitur. Jika kemudian debitur tidak beritikad baik untuk melunasi utangnya, maka jalan yang dapat ditempuh kreditur konkuren adalah dengan melakukan gugatan perdata kepada pengadilan negeri setempat sekaligus meminta agar ditetapkannya sita jaminan terhadap harta atau barang milik debitur (conservatoir beslag) agar pelunasan utang debitur tersebut dapat dipenuhi dengan baik. ${ }^{26}$

Debitur yang merupakan CV, meninggalnya sekutu komplementer tidak akan terlalu berpengaruh bagi kreditur preferen. Hal ini dikarenakan kreditur preferen memiliki jaminan kebendaan dan dilindungi oleh undang-undang yang akan menjamin dilunasinya piutang yang dimiliki. Sedangkan bagi kreditur konkuren, meninggalnya sekutu komplementer akan menyebabkan pelunasan piutangnya menjadi terkendala dan gugatan yang akan diajukan menjadi tidak jelas pihak mana atau siapakah yang akan digugat untuk melunasi piutang tersebut.

Sesuai dengan pembahasan sebelumnya, sekutu yang menggantikan kedudukan sekutu komplementer (baik ahli waris maupun sekutu CV lainnya) adalah sekutu yang akan bertanggung jawab atas semua utang-utang CV. Dengan demikian, meskipun ahli waris menolak untuk membayar utang pewaris yang merupakan utang $\mathrm{CV}$, kreditur konkuren dapat menuntut pelunasan utang tersebut kepada sekutu komplementer baru yang mengelola CV setelah meninggalnya sekutu komplementer lama.

\footnotetext{
25 Boedi Harsono, Hukum Agraria Indonesia Sejarah Pembentukan Undang-Undang Pokok Agraria, Isi dan Pelaksanaannya Jilid 1 Hukum Tanah Nasional, Cetakan Kesepuluh, Djambatan, Jakarta, 2005, hlm. 328.

${ }^{26}$ Sri Wardah dan Bambang Sutiyoso, Hukum Acara Perdata dan Perkembangannya di Indonesia, Gama Media, Yogyakarta, 2007, hlm. 78.
} 
Masalah utama yang harus diketahui oleh kreditur konkuren adalah siapakah sekutu baru yang akan menggantikan sekutu komplementer yang lama. Oleh karena itu, untuk mendapatkan kepastian siapakah pihak yang bertanggung jawab kreditur konkuren harus meminta salinan akta pendirian $\mathrm{CV}$ tersebut sebelum perjanjian utang piutang itu terjadi, dengan dimilikinya akta pendirian CV, kreditur konkuren akan dapat mengetahui siapa saja yang bertanggung jawab jika terjadi hal-hal yang tidak diinginkan dalam CV tersebut. Jika terjadi perubahan kedudukan sekutu, peralihan tanggung jawab dan penggantian pihak yang menjabat sebagai sekutu CV akan dapat diketahui oleh kreditur konkuren sehingga akan memberikan kepastian siapa yang bertanggung jawab dan dapat ditagih untuk melunasi utang tersebut. Dengan demikian, meskipun ahli waris menolak untuk menggantikan kedudukan pewaris, selama CV itu tetap berjalan, kreditur konkuren tetap dapat menuntut pelunasan piutangnya kepada CV melalui sekutu komplementer baru yang menggantikan sekutu komplementer lama sebagaimana yang telah di bahas di atas.

\section{Penutup}

Berdasarkan penelitian tersebut di atas dapat disimpulkan, pertama, perlindungan hukum terhadap hak ahli waris sekutu komplementer atas harta warisan yang telah menjadi jaminan utang $\mathrm{CV}$ adalah dengan menentukan secara tegas di dalam akta pendirian CV bahwa perubahan kedudukan sekutu yang menggantikan kedudukan sekutu lain menimbulkan kewajiban untuk menanggung tanggung jawab sekutu yang digantikan. Dengan demikian, jika ahli waris masuk ke dalam CV sebagai sekutu komanditer, maka sekutu komplementer baru memiliki kewajiban untuk mengembalikan harta waris sekutu komplementer lama yang telah menjadi jaminan utang CV kepada ahli warisnya, kecuali jika dapat dibuktikan bahwa sekutu komplementer lama memiliki utang kepada CV yang harus dibayarkan dengan jaminan harta waris tersebut.

Kedua, perlindungan hukum yang diberikan kepada kreditur CV jika sekutu komplementer meninggal dunia dan ahli waris sekutu tersebut tidak bersedia bertanggung jawab menggantikan pewarisnya adalah tanggung jawab atas utang tersebut tetap menjadi tanggung jawab CV dan sekutu komplementer baru yang menjalankan CV tersebut. Kreditur konkuren sebagai kreditur yang paling lemah 
dapat meminta salinan akta pendirian $\mathrm{CV}$ tersebut sebelum perjanjian utang piutang itu terjadi untuk memastikan mengenai siapakah sekutu yang bertanggung jawab jika terjadi pergantian kedudukan dalam CV. Jika terjadi perubahan kedudukan sekutu, peralihan tanggung jawab dan penggantian pihak yang menjabat sebagai sekutu CV akan dapat diketahui oleh kreditur konkuren sehingga akan memberikan kepastian siapa yang bertanggung jawab dan dapat ditagih untuk melunasi utang tersebut.

Berdasarkan hasil penelitian di atas, disarankan bahwa, pertama, sebagai pihak yang merumuskan dan membuat akta pendirian $\mathrm{CV}$, seorang Notaris harus memiliki pemahaman yang mendalam mengenai CV agar kesepakatan sekutu untuk mempertahankan CV dapat dijalankan dengan baik dan memberikan perlindungan hukum bagi seluruh pihak terutama bagi ahli waris dan kreditur CV. Hal ini dikarenakan akta pendirian CV merupakan aturan dasar dan pedoman utama bagi para sekutu CV dalam menjalankan CV. Dengan demikian, kesempurnaan akta pendirian CV tersebut dalam mengatur segala hal yang akan dilakukan CV harus sangat diperhatikan dan ditaati oleh para sekutu CV.

Kedua, penelitian ini masih memiliki beberapa rumusan masalah yang dapat digunakan untuk melakukan penelitian lanjutan seperti misalnya mengenai tanggung jawab ahli waris atas utang CV yang bukan merupakan utang pewaris secara pribadi berdasarkan Hukum Islam, dan mengenai klausula-klausula yang harus ditentukan dalam akta pendirian CV yang tidak akan bubar dengan meninggalnya seorang sekutu CV. Oleh karena itu, peneliti merekomendasikan untuk dilakukan penelitian lanjutan tentang masalah-masalah tersebut.

\section{Daftar Pustaka}

\section{Buku}

Harahap, M. Yahya, Hukum Perseroan Terbatas, Cetakan Kedua, Sinar Grafika, Jakarta, 2009.

Harsono, Boedi, Hukum Agraria Indonesia Sejarah Pembentukan Undang-Undang Pokok Agraria, Isi dan Pelaksanaannya Jilid 1 Hukum Tanah Nasional, Cetakan Kesepuluh, Djambatan, Jakarta, 2005.

Jono, Hukum Kepailitan, Cetakan Kedua, Sinar Grafika, Jakarta, 2010. 
Kansil, C.S.T dan Christine S.T. Kansil, Pokok Pokok Pengetahuan Hukum Dagang Indonesia, Cetakan Kedua, Sinar Grafika, Jakarta, 2004.

Kumortomo, Wahyudi, Etika Administrasi Negara, Rajawali Press, Jakarta, 2011.

Purwosutjipto, HMN, Pengertian Pokok Hukum Dagang Indonesia 2 Bentuk-Bentuk Perusahaan, Cetakan Kesebelas, Djambatan, Jakarta, 2007.

Ridwan, Hukum Administrasi Negara, Edisi Revisi, Rajawali Press, Jakarta, 2014.

Simatupang, Richard Burton, Aspek Hukum Dalam Bisnis (Edisi Revisi), Rineka Cipta, Jakarta, 2004.

Soebekti, Jaminan-Jaminan untuk Pemberian Kredit Menurut Hukum Indonesia, Alumni, Bandung, 1982.

Wardah, Sri dan Bambang Sutiyoso, Hukum Acara Perdata dan Perkembangannya di Indonesia, Gama Media, Yogyakarta, 2007.

Widjaja, Gunawan, Seri Aspek Hukum dalam Bisnis: Persekutuan Perdata, Persekutuan Firma dan Persekutuan Komanditer, Edisi 1, Cetakan Kedua, Kencana, Jakarta, 2006.

\section{Jurnal}

Alsa, Abdul Aziz dan Ningrum Natasya Sirait, et.al., "Pertanggungjawaban Pidana Badan Usaha Berbentuk CV (Commanditaire Vennootschap) Dalam Perlindungan dan Pengelolaan Lingkungan Hidup," USU Law Journal, Vol. 3. No. 3, November 2015.

Hariyani, Iswi, “Kajian Hukum Restrukturisasi Asuransi Jiwa Bersama Bumiputera 1912 sebagai Perusahaan Mutual", Jurnal Hukum IUS QUIA IUSTUM, No. 2 Vol. 24 April 2017.

Nadriana, Lenny dan Eman Suparman, "Tanggung Jawab Ahli Waris dari Penjamin pada Perusahaan yang Pailit Ditinjau dari Hukum Waris Islam", Jurnal Hukum IUS QUIA IUSTUM, No. 3 Vol. 24, 28 Februari 2018.

Simorangkir, Julius Caesar Transon, “Tanggung Jawab Sekutu Maatschap Terhadap Pihak Ke 3 dalam Suatu Perjanjian Konsorsium Terkait Bubarnya Maatschap atas Kehendak Para Sekutu (Kasus Perjanjian Konsorsium antara PT Agro Bintang Dharma Nusantara dengan Pemerintah Daerah Balikpapan, Bontang, Kutim dan Paser)" Fiat Justisia Jurnal Ilmu Hukum, Volume 9, No. 2, April-Juni 2015.

Suari, Kadek Rima Anggen dan I Nengah Suantra, “Tanggung Jawab Sekutu Terhadap Commanditaire Vennootschap (CV) yang Mengalami Pailit", Kertha Semaya, Fakultas Hukum Universitas Udayana, Vol. 06, No. 02, Maret 2018.

\section{Peraturan Perundang-Undangan:}

Kitab Undang-Undang Hukum Perdata (KUHPerdata)

Kitab Undang-Undang Hukum Dagang (KUHD). 